\title{
Impact Load Behaviour of Resin Transfer Moulding (RTM) Hemp Fibre Composite Laminates
}

\author{
C. Scarponi ${ }^{1}$, C. S. Pizzinelli ${ }^{1}{ }^{*}$, S. Sánchez-Sáez ${ }^{2}$, and E. Barbero ${ }^{2}$ \\ ${ }^{1}$ Sapienza Università di Roma, Dipartimento di Ingegneria Aerospaziale e Astronautica, Via Eudossiana 18, 00184 Roma, Italia \\ ${ }^{2}$ Departamento de Mecanica de Medios Continuos y Teoria de Estructuras, Universidad Carlos III de Madrid, \\ Avda. de la Universidad 30-28911 Leganés (Madrid), Spain
}

\begin{abstract}
Aim of this work is to determine experimentally some important mechanical characteristics of RTM hemp plain weave fabric/epoxy laminates. Equipment and test methods are described and critically discussed. Main subjects of this work are: RTM process improvement, preliminary tensile and flexural tests and impact performance. The latter is analyzed with particular attention, also comparing data with other experimental results. Attention is devoted both to the process, which strongly influences the mechanical performance of natural long fibres reinforced composites and to the low-velocity impact behaviour. This is a very important requirement for future aeronautical applications, in that composite structures should retain sufficient residual compression properties (CAI: Compression After Impact) after a Barely Visible Impact Damage (B.V.I.D).
\end{abstract}

Keywords: Natural Fibres, Hemp, Composites, Impact, RTM, Fabric.

\section{INTRODUCTION}

\subsection{Natural Fibers}

Over the last years, increasing environmental consciousness and awareness of the need for sustainable development have sparked renewed interest in the development of composite materials reinforced with natural fibers (NFC). Natural fibers (NF) have good specific mechanical properties such as specific strength and stiffness. For this reasons they may be used as a low-cost, low-weight, biodegradable, reduced tool wear, ${ }^{1}$ renewable, non-toxic, carbon dioxide neutral reinforcement for polymer matrices alternative to glass fibers. In consideration of the fact that it is possible to utilize more or less same processes, tools, labor, equipments, controls and know-how, an easy reinforcement substitution is possible and not so expansive.

The demand for NF in plastic composites is forecast to grow $15-20 \%$ annually with a growth rate of $15-20 \%$ in automotive applications and even more than $50 \%$ in some building applications. ${ }^{2,3}$

\subsection{Situation in Aeronautics and Requirements}

In aeronautical structures the situation is complex because of high load levels, mechanical and/or thermal and/or

-Author to whom correspondence should be addressed. Email: sebarm86@hotmail.com acoustic fatigue, requirements of durability, reliability and maintenance, reproducibility of mechanical characteristics, "confidence" on material's performance and, in particular, certification requirements. For such reasons, the substitution with a new material has a high impact on costs and times required by the certification procedure. The process is usually long and expensive in terms of testing and numerical simulations. For these reasons it has been selected a step by step procedure: efforts have been made in our Department in four main lines, in order to improve/determine:

- quality of processes

- mechanical characteristics and their reproducibility

- impact strength

- Life Cycle Assessment (LCA) \& environmental impact.

The aim was to achieve a good chemical/physical and mechanical characterization, focusing on the reproducibility of mechanical properties among various production lots/stocks.

The fabrication process has an important role in material's mechanical performances and costs. In particular, the use of fabrics, with the RTM fabrication process, has been selected for the present study. In fact, becausc of its advantages, such as good quality, reliability and especially, reduction of materials and manufacturing costs (main item), RTM process is widely used for aeronautical 
composite structures, also by the realization of complex stitched pre-forms, to be processed in one shot. These two items are key aspects in this study.

In aircraft design, particularly for external structures, loads to be considered include impact events such as dropped tools, debris from runways, hailstones, bird strike.... This may result in a large internal damaged area of the laminate that is not detectable from visible observation. Variable service loads can continuously grow the damage area, possibly resulting in complete structural collapse of the damaged part. ${ }^{4}$

\subsection{Aim of This Study}

Although in practice the use of natural fiber-reinforced plastic is continually increasing, there is still a poor understanding of certain aspects of their behavior, such as their response to impacts and the influence of process parameters on mechanical performance. In the scientific literature only few studies have been carried on about CFN impact response and mostly involving short fibers, while there are few data regarding behavior of composites made with fabrics.

The purpose of the present study is to investigate the behavior of composites laminates reinforced by hemp fabric, processed by RTM. In particular aims of this work are:

- to improve the RTM process in order to obtain higher quality laminates

- to determine by testing the effect of damage caused by low velocity impact loading, to be compared with the results obtained by the same authors in similar conditions (specimen mass, geometry, impact energies, impactor and boundary conditions) by previous studies conducted on jute, glass and jute/glass hybrid laminates. ${ }^{5.6}$

Before of the impact tests, mechanical tests (traction and bending), have been performed in order to verify the quality of the material and of the fabrication process.

The research has been conducted with the following items:

- pure resin tension tests (in line with the RTM device testing);

- hemp composites tension and bending tests;

- impact tests;

- results comparison.

\section{IMPACT ON NFC IN LITERATURE}

Many researchers, (such as Abrate, Anderson, Chang, Dhakal, Kerక̌ienë and Žiliukas, Mueller and Krobjilowski Scarponi et al., Santulli and Cantwell, Tita et al. ${ }^{7-22}$ ) have evidenced also experimentally the damage status deriving from low velocity impact loads.

In particular researches on this subject but with $\mathrm{NF}$ as a reinforcement have been conducted by, Dhakal, Keršienë and Žiliukas, Mueller and Krobjilowski, Scarponi et al., Santulli and Cantwell, Dhakal, Mueller and Krobjilowski, Scarponi et al., Santulli and Cantwell. ${ }^{5.6 .13-16}$

Scarponi et al. ${ }^{5.6 .21 .22}$ investigated the impact behavior of jute/vinylester, glass/vinylester and hybrids in order to verify the possible substitution/integration of $\mathrm{NF}$ instead of Glass-fibers.

Santulli ${ }^{13.14}$ studied the post-impact behavior of jute/polyester composites and pointed out that their interlaminar adhesion is sufficient to yield an impact damage pattern typical of stronger composites, often referred to as "reversed-pine tree pattern" (see also Section 2).

Dhakal ${ }^{15}$ dealt with polyester reinforced with needle punched random nonwoven hemp fibers and from impact test results it was shown that the total impact energy absorbed by $21 \%$ fiber volume ( 4 layered) hemp reinforced specimen is comparable to the total energy absorbed by $21 \%$ fiber volume chopped strand mat E-glass reinforced specimens.

Mueller and Krobjilowski ${ }^{16}$ described the effects of several material parameters and process conditions on impact strength of flax hemp and kenaf composites. It can be seen from their work that increasing the share of reinforcing fiber in the composite, the maximum of impact strength moves to higher processing temperatures because, increasing the fiber volume, a better fiber impregnation due to lower binder viscosity, predominates over the weakening thermal decomposition.

It can be said briefly that it is likely to expect different types of damage, depending on the specimen geometry and impact energy; in particular at relatively low impact energies damages initiate with matrix cracking, fiber-matrix debonding and delamination, while at higher energies, damage also occurs by fiber fracture and pull-outs. In low velocity impact loadings, the fiber-matrix adhesion can further affect the failure mode which occurs at a given load (i.e., poor adhesion results in failure at low transverse stress, exposing free fibers). In general, impact on composites with weak interfacial adhesion produce large delaminated areas with strong effects on residual properties, while localized impact loading on composites with strong interfaces results in a smaller, more localized damage zone, with higher residual compressive properties of the composite.

\section{EXPERIMENTAL PROCEDURE}

\subsection{Materials}

After a preliminary phase in which some process parameters (degassing technique, excess resin collecting, pressuretime curve...) have been improved in order to have an enhanced process that could lead to panels with satisfactory fulfillment of previously set requirements. More detail will be discussed in the following sections. 
Table 1. Density and viscosity of hardener, pre-polymer and mix.

\begin{tabular}{lccc}
\hline & $\begin{array}{c}\text { Epoxy Resin } \\
\text { SR } 1710\end{array}$ & $\begin{array}{c}\text { Curing catalyst } \\
\text { SD8824 }\end{array}$ & $\begin{array}{c}\text { SR1710/SD8824 } \\
\text { Mix } 100 \mathrm{ml} / 28 \mathrm{ml}\end{array}$ \\
\hline $\begin{array}{l}\text { Viscosity [mPa*s] } \\
20^{\circ} \mathrm{C}\end{array}$ & 1300 & 8 & 205 \\
$25^{\circ} \mathrm{C}$ & 800 & 6 & 120 \\
Density $\left[\mathrm{g} / \mathrm{cm}^{3}\right]$ & & & $1.106^{a}$ \\
$20^{\circ} \mathrm{C}$ & 1.152 & 0.942 & \\
\hline
\end{tabular}

${ }^{u}$ Calculated data.

Table II. Properties of the hemp tissue used for this studies.

\begin{tabular}{|c|c|}
\hline Linear mass density (average) ${ }^{a}(\mathrm{Tex})$ & 71.7 \\
\hline Pretensioning strength ${ }^{a}(\mathrm{cN} / \mathrm{Tex})$ & 0.5 \\
\hline Density (average) $\left(\mathrm{gr}^{\mathrm{c}} \mathrm{cm}^{3}\right)$ & 1.7 \\
\hline Maximum strength ${ }^{b}(\mathrm{MPa})$ & $590 \pm 150$ \\
\hline Young Modulus (GPa) & $18=4$ \\
\hline Elongation at break in traction (average) ${ }^{r}(\%)$ & $4 \pm 0.3$ \\
\hline Specific areal weight ${ }^{a}\left(\mathrm{gr} / \mathrm{m}^{2}\right)$ & 244 \\
\hline Price $^{b}$ (Euro/meter $\left.^{2}\right)$ & 12 \\
\hline
\end{tabular}

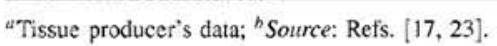

\subsubsection{Matrix}

It has been selected an epoxy resin, because of its excellent mechanical properties, in particular for its resistance to interlaminar shear (once it has become the matrix of the laminate).

The resin and the curing catalyst have been mixed in the volumetric ratio of $100 / 28 \mathrm{ml} / \mathrm{ml}$, as presented in Table I, and then the mixture has been degassed (see also Section 1.2).

\subsubsection{Fibers}

The fabric used for specimens is a "plain weave," provided by National Canapificio Linificio-Spa of Verona; main characteristics of tissue and thread are reported in Table II. In particular, density has been calculated knowing the density of the laminate and the resin (assuming a negligible void content).

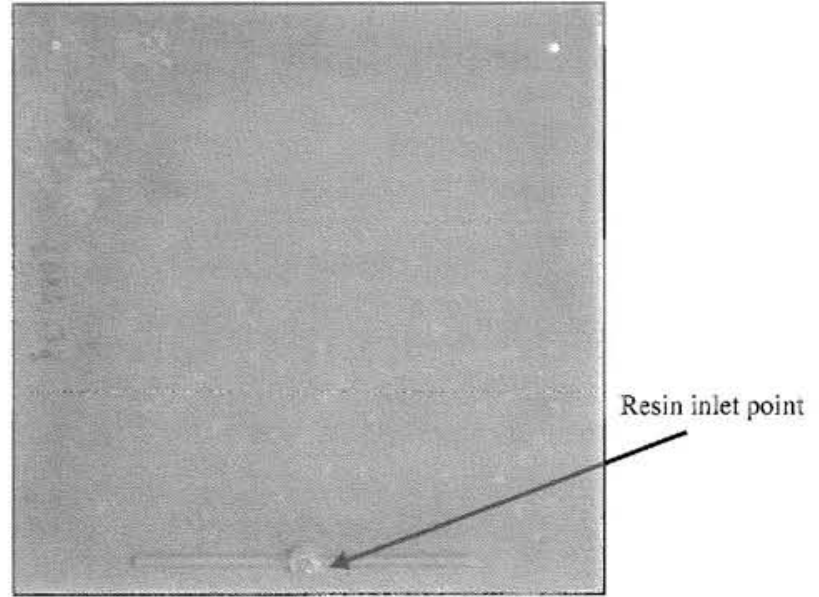

Fig. 2. Hemp-epoxy $400 \mathrm{~mm}$ square panel $5 \mathrm{~mm}$ thick $\left(0^{\circ} 90^{\circ}\right)$ made of 14 plies.

For the tissue in question, from the micrographies of threads and fibers in Figure 1 rough and irregular surfaces are apparent, suggesting that a longer time is needed for resin injection (see also Section 3.3).

The retting technology and the particular chemical treatments applied to this fabric to facilitate the operation of weaving are not known. In fact for the physical and chemical treatments used to improve adherence fiber/matrix in the specific case of this hemp fabric textile, treatments performed (alkalinization with sodium hydroxide $\mathrm{NaOH} 1 \% \mathrm{wt}$ ) did not produce convenient performance increase. ${ }^{17}$ According to the authors, the fibers have probably been chemically pre-treated, also because results obtained with chemically treated fibers do not agree with data that can be found in literature.

\subsection{Specimens}

After the process enhancement (see par. 3.3 for more details) for specimens it has been used panel2 (Fig. 2), made of 14 plies of tissue; panel's main properties are

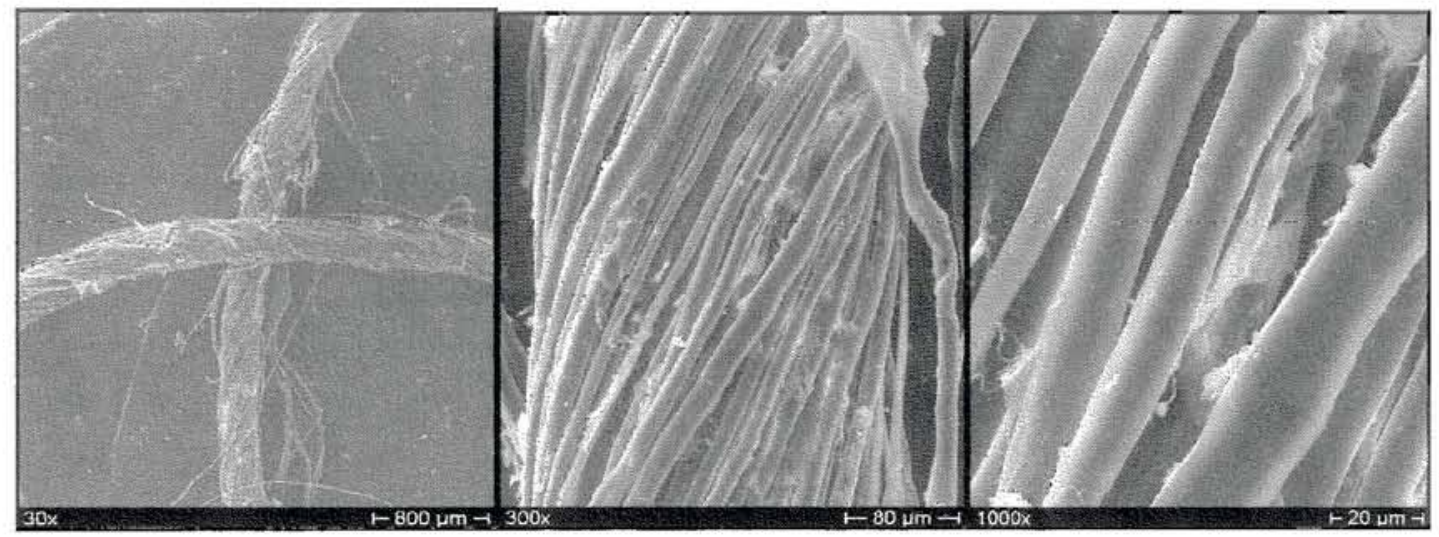

Fig. 1. Hemp micrographies of 2 threads (left), zoom on one thread (center), further zoom on the fibers (right). 
Table III. Properties of the hemp plain weave tissue/epoxy RTM laminates.

\begin{tabular}{|c|c|c|c|c|}
\hline Panel properties & Panel 1 base RTM & $(\%)$ & Panel 2 enhanced RTM & $(\%)$ \\
\hline Total weight (g) & 880 & - & 1084.5 & - \\
\hline Fibers weight (g) & 367.7 & 42 & 520 & 48 \\
\hline Resin weight (g) & 512.3 & 58 & 564.5 & 52 \\
\hline Area $\left(\mathrm{cm}^{2}\right)$ & $40 * 33=1320$ & - & $40 \times 40=1600$ & - \\
\hline Thickness (mm) & 5.1 & - & 5.1 & - \\
\hline Volume $\left(\mathrm{cm}^{3}\right)$ & 673.20 & - & 816 & - \\
\hline Density (panel) $\left(\mathrm{g} / \mathrm{cm}^{3}\right)$ & 1.307 & - & 1.329 & - \\
\hline Dry fibers density $\left(\mathrm{g} / \mathrm{cm}^{3}\right)$ & 1.7 & - & 1.7 & - \\
\hline$V$ resin $\left(\mathrm{cm}^{3}\right)$ & 463.18 & 68.8 & 510.37 & 62.5 \\
\hline V fibers $\left(\mathrm{cm}^{3}\right)$ & 210.02 & 31.2 & 305.73 & 37.5 \\
\hline No. of fabric plies & 12 & - & 14 & - \\
\hline
\end{tabular}

listed in Table III. On the top surface can be seen some imperfections, probably caused by entrapped air. From this panel have been obtained which 9 specimens for the impact tests ( 3 for each energy level) and 6 for bending tests and 5 for traction.

\subsection{Processing}

Among the various processes it has been selected the RTM for the reasons briefly explained in par 1.2.

In this work two laminates have been realized (see par. 3.2 for more details): panel 1 with the base RTM process and panel 2 (Fig. 3) after having enhanced the process and changed some parameters.

Panels fabrication has been performed at the Centro Sviluppo Materiali laboratories, with a Plastech T.T. machine, characterized by three main subsystems:

- command console

- homogenizer (the degassing is performed here only for the first panel)

- mold
The mold $(400 \times 400 \mathrm{~mm})$ is connected to an electrical power unit whose task consists in heating the plate in order to maintain the desired temperature. On the mold there are some little holes for the excess resin flow. The resin, after being aspired from the homogenizer, is degassed (this process has been carried out differently in the second laminate). Subsequently the mixture has been raised to the injecting temperature and injected into the mold through an air-assisted valve and then pressure has been gradually increased.

Before starting the process, mold and countermold have been well cleaned and then treated with a releasing agent (Loctite), then all the tissue reinforcements layers have been placed on the mold, with a symmetrical orientation $0^{\circ} 190^{\circ}$. This layup has been selected in order to avoid any possible asymmetry problems or differences between warp and weft directions. Subsequently, before resin injection at the initial pressure of $0.5 \mathrm{bar}$, the mold has been closed and inside vacuum has been made. When the resin has wet half tissue, the injection pressure has been increased and kept to 3 bar in order to the complete impregnation. In

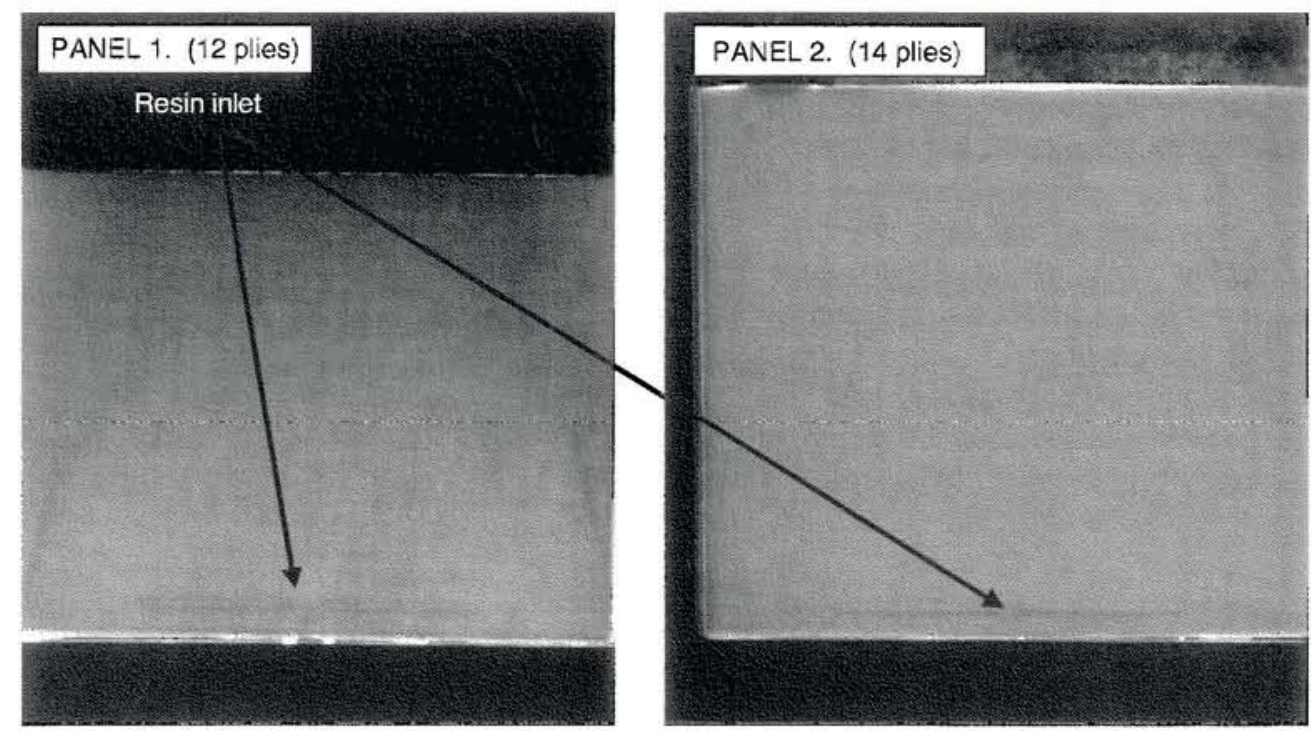

Fig. 3. Panel compared in backlight; an improved resin distribution is apparent in panel 2. 

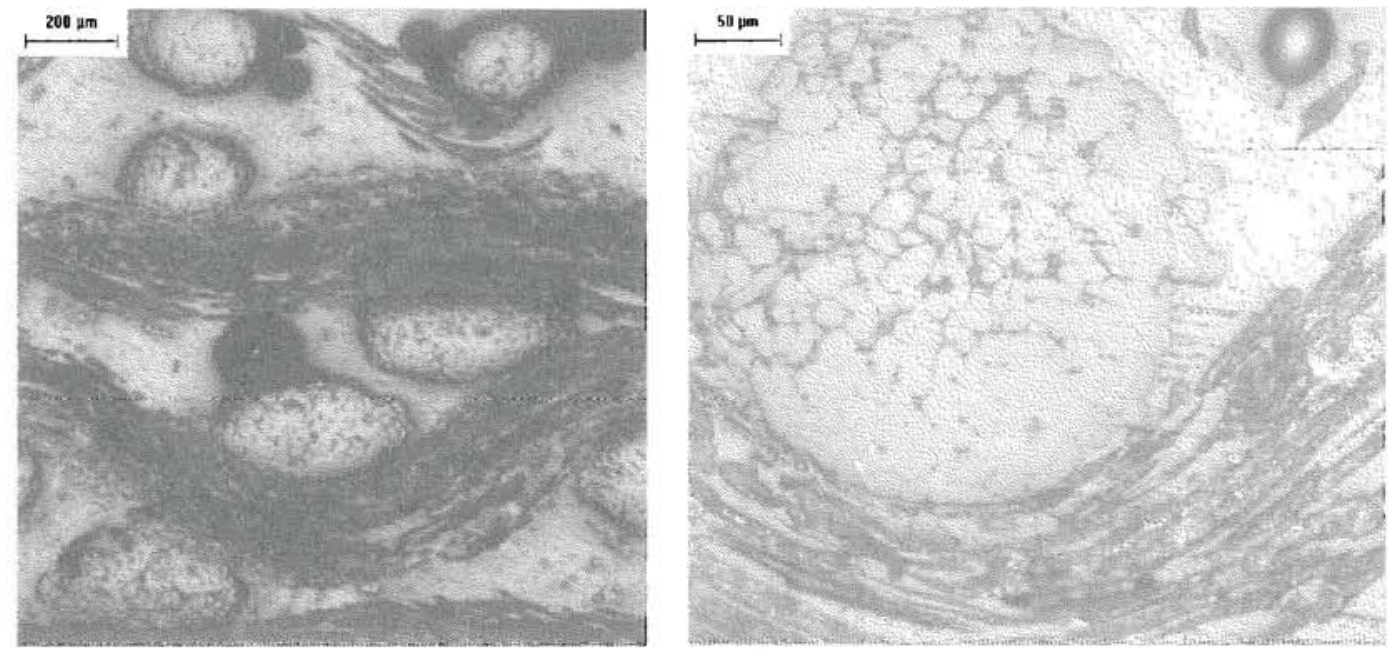

Fig. 4. Micrography of panel 1 show fractures between the bundle and the presence of voids.

the enhanced process the pressure has been kept slightly under 3 bar in order to avoid gasket failure.

Resin speed depends on many factors, and in particular from viscosity and from the material, characteristics and geometry of reinforcements layers (see also Section 3.1.2). In this case the fabric is "coarse" with low porosity and so a high resistance is encountered from the resin flow. In fact the whole operation has taken place in $8 \mathrm{~min}$, and about $2 \mathrm{~min}$ have been necessary before the resin has been visible on the fabric.

Polymerization occurs in two stages:

- pre-curing, for 6 hours at room temperature

- curing, for the subsequent $24 \mathrm{~h}$ at $40^{\circ} \mathrm{C}$.

In Figure 3 both panels are compared: panel 1 (left) it not satisfactory, due to bad wetting and non uniform resin distribution while panel 2 (right) shows a more uniform resin distribution. To achieve a better understanding of the problems and the situation, a series of micrographies have been conducted on the first panel (Fig. 4). From these pictures it is clearly possible to see that technical fibers show fractures between the bundle and the presence of voids.

In order to improve the mechanical performance of the final product, the fiber content has been increased and some process parameters have been changed/improved. In particular the resin degassing for the second laminate has been carried out using a system consisting of an outer bottle connected to a compressor and to the mold (Fig. 5). The "bottle" has been introduced in order to put an end to the degassing stage when the foam (typical of this process) was no longer visible on the surface of the hardenerprepolymer mixture.

Another improvement that has been introduced to enhance the process is the "resin trap" (Fig. 6); it consisted in a glass jar which prevents the excess resin flow to go back into the pump system. This "trapped" resin was also analyzed (see Section 5.1 for further details).

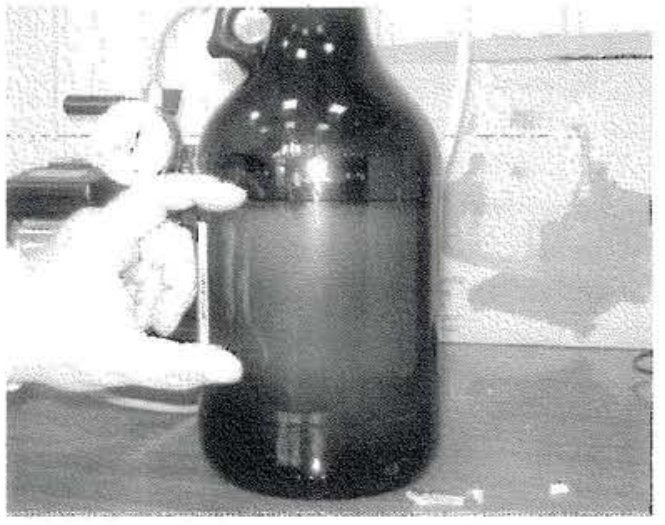

Fig. 5. Degassing; it is visible the typical "foam."

\subsection{Specimens Cutting}

Composite panels have been cut to obtain samples in accordance with standards for each mechanical test for which specimens are intended. In particular, for the tensile test tabs have been fixed to specimens using epoxy glue,

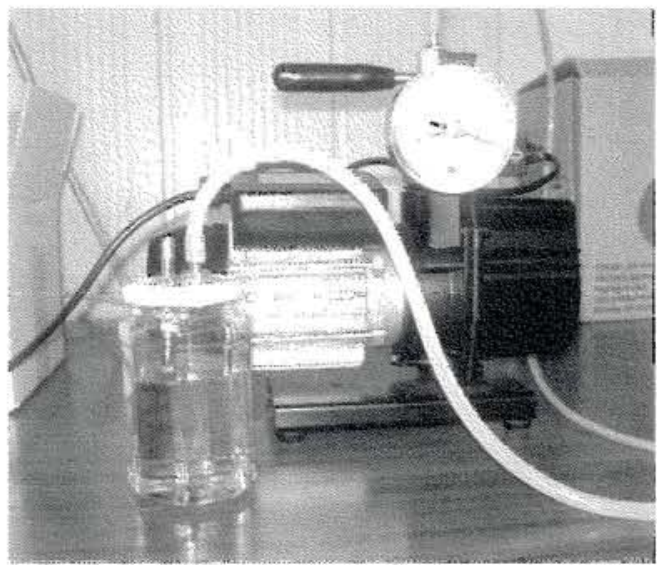

Fig. 6. The "resin trap" prevents the excess resin flow to go back into the pump. 
applied on the surface of the samples previously sanded, in order to achieve a good bonding between the two surfaces.

Specimens for dog-bone shaped pure resin, according to the D638 normative, were made by a rubber mold and cured at room temperature.

\section{TESTING PROCEDURE}

\subsection{Tensile Test}

Tensile tests were performed using a Zwick machine at room temperature, with a load cell of $250 \mathrm{kN}$, to determine: Young's module, Poisson ratio, tensile strength and elongation at break. Tests have been conducted following the normative ASTM D3039, on five $250 \times 25 \times 5 \mathrm{~mm}$ specimens.

\subsection{Flexural Test}

For this testing is has been used a MTSI.D.AST 1 machine which has a maximum applicable load of $200 \mathrm{kN}$.

The 4 point bending test (4PBT) was selected instead of the 3 PBT because it gives more reliable results. Tests have been conducted on 6 specimens of $190 \times 13 \times 5 \mathrm{~mm}$ and at a speed of $8.1 \mathrm{~mm} / \mathrm{min}$. Geometry of samples, conditions and procedure follows the ASTM D790-86 standard.

\subsection{Impact Test}

The falling weight machine (Fig. 7) is equipped with an anti rebound system and allowed variation of the mass, by means of removable weights (ASTM D5628-96, ASTM D5428-98th).

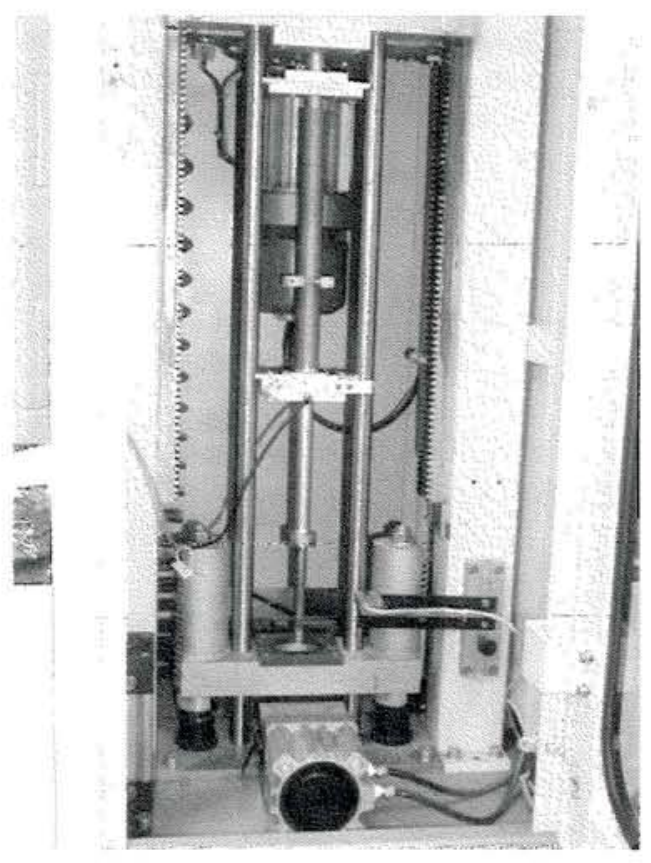

Fig. 7. Low velocity impact test machine.

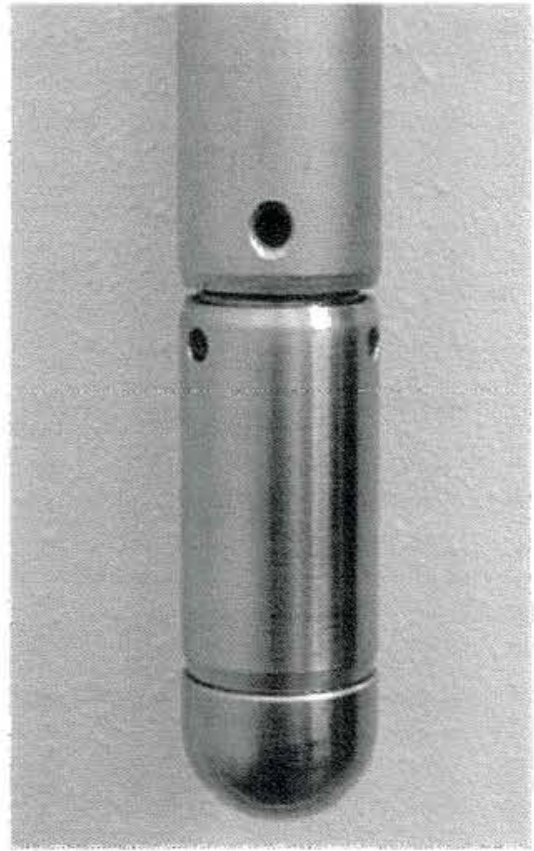

Fig. 8. Impactor head.

Square specimens $100 \times 100 \mathrm{~mm}$ have been utilized for the impact test ( 3 for each energy level). Specimens were bounded with a rectangular clamping

The test has been conducted for three different levels of energy: $5 \mathrm{~J}, 10 \mathrm{~J}, 15 \mathrm{~J}, 3$ specimens for each level. The hemispherical head impactor has a mass of $3.966 \mathrm{Kg}$ and a diameter of $12.7 \mathrm{~mm}$ (Fig. 8). Striker's speed were respectively $1.59 \mathrm{~m} / \mathrm{s}, 2.25 \mathrm{~m} / \mathrm{s}$, and $2.75 \mathrm{~m} / \mathrm{s}$.

The choice of these energies allows us to make the comparison with a previous series of tests conducted by Briotti et al. ${ }^{5,6}$ as will be discussed in par. 5.3.

The speed of the body at the impact is measured by a photocell. From data elaboration, it is possible to obtain the impact speed $v$ and the contact force $F(t)$ between the striker and the target. Denoting with $P$ the impact force and with $m$ the impactor mass the acceleration $a(t)$ and the energy released from the impactor until time $t$ can be calculated as:

$$
\begin{gathered}
a(t)=\frac{F(t)-p}{m} \\
e(t)=\int_{0}^{t} F(t)\left[v_{0}-\int_{0}^{t} \frac{F(t)-P}{m} d \tau\right] d \tau^{*}(\text { Ref. [11]) }
\end{gathered}
$$

\section{RESULTS AND DISCUSSION}

\subsection{Tensile Tests}

The trend of the stress-strain curve (Fig. 9) is elastic, but not linear until rupture, that occurs at a stress of about $93 \mathrm{MPa}$ and a deformation of $1.9 \%$. At first sight the curve can be divided in two quasi-linear areas each with 


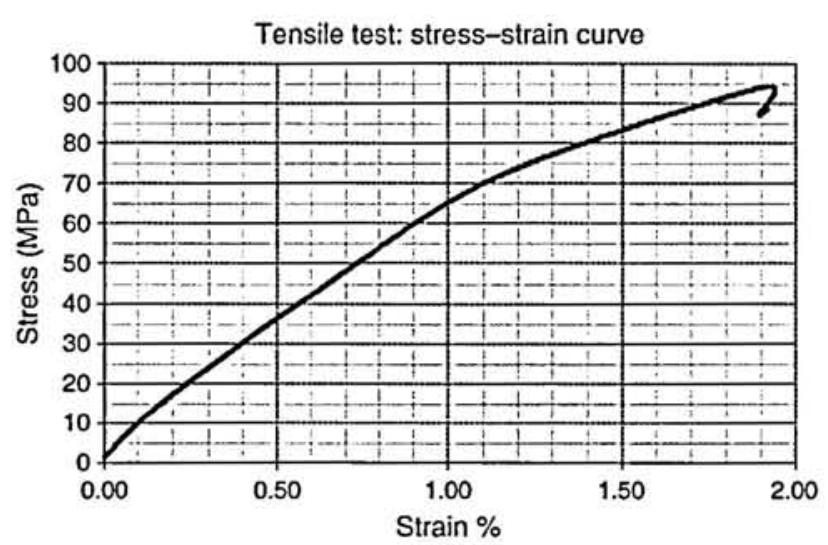

Fig. 9. Stress-strain curve of a single specimen of hemp plain weave fabric/epoxy laminate.

Table IV. Some mechanical properties of hemp and E-glass reinforced composites. $^{23.26,27.28 .29}$

\begin{tabular}{lcccc}
\hline Material & $\begin{array}{c}\text { Tensile } \\
\text { strength } \\
(\mathrm{MPa})\end{array}$ & $\begin{array}{c}\text { Young } \\
\text { Module E } \\
(\mathrm{GPa})\end{array}$ & $\begin{array}{c}\text { Rupture } \\
\text { load } \\
(\mathrm{N})\end{array}$ & $\begin{array}{c}\text { Strain } \\
\text { (rupture) } \\
(\%)\end{array}$ \\
\hline $\begin{array}{c}\text { Hemp/Epoxy } \\
\text { Coefficient of } \\
\text { variation }\end{array}$ & $\begin{array}{c}93.77 \pm 3.22 \\
3.43 \%\end{array}$ & $\begin{array}{c}6.10 \pm 0.17 \\
2.76 \%\end{array}$ & $\begin{array}{c}9542.50 \\
1.9 \pm 0.2\end{array}$ & \multicolumn{1}{c}{$10.5 \%$} \\
$\begin{array}{c}\text { Hemp/Epoxy } \\
\text { (Literature) } \\
\text { (plain weave) }\end{array}$ & $40-100$ & $5-10$ & $/$ & $/$ \\
$\begin{array}{c}\text { E-Glass/Epoxy } \\
\text { (Literature) } \\
\text { (plain weave) }\end{array}$ & $210-280$ & $16-19$ & $/$ & $1.2-1.3$ \\
\hline
\end{tabular}

Table V. Tensile properties of epoxy resin specimens.

\begin{tabular}{lccc}
\hline & $\begin{array}{c}\text { Strength } \\
(\mathrm{MPa})\end{array}$ & $\begin{array}{c}\text { Modulus } \\
(\mathrm{GPa})\end{array}$ & $\begin{array}{c}\text { Strain at } \\
\text { rupture (\%) }\end{array}$ \\
\hline Pure resin & $59.21 \pm 0.76$ & $3.3 \pm 0.1$ & $1.81 \pm 0.25$ \\
\hline
\end{tabular}

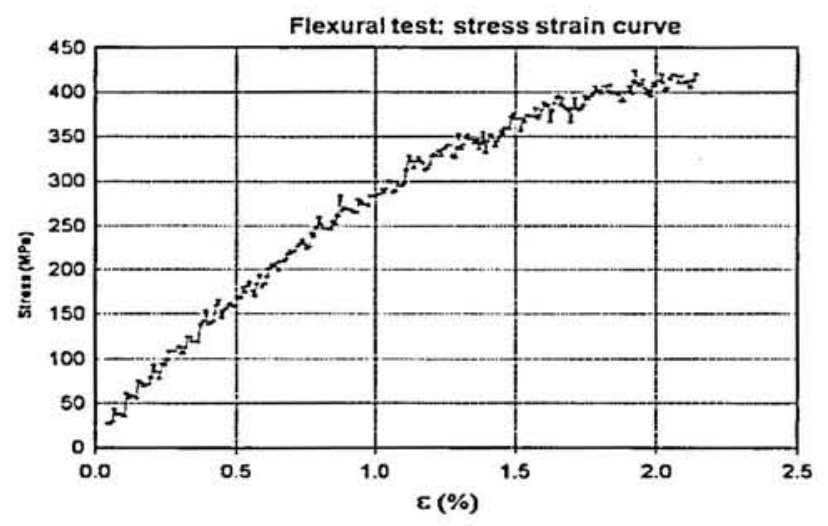

Fig. 10. 4PBT stress-strain curve for an hemp plain weavelepoxy specimen.

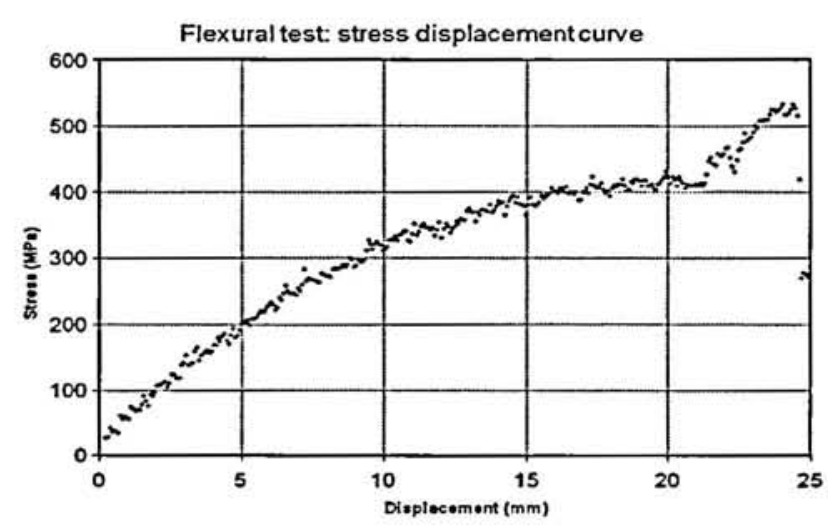

Fig. 11. 4PBT stress-displacement curve for an hemp plain weave/ epoxy specimen.

Table VI. 4PBT results for hemp plain weave reinforced composites.

\begin{tabular}{lccc}
\hline & $\begin{array}{c}\text { Flexural } \\
\text { strength (MPa) }\end{array}$ & $\begin{array}{c}\text { Flexural } \\
\text { modulus }(\mathrm{GPa})\end{array}$ & $\begin{array}{c}\text { Max load } \\
(\mathrm{N})\end{array}$ \\
\hline Average & $145 \pm 9.4$ & $11.87 \pm 1.65$ & $416.33 \pm 22.6$ \\
Coefficient of variation & $6.48(\%)$ & $13.9(\%)$ & $5.43(\%)$ \\
\hline
\end{tabular}

a different slope. This curve exhibits the typical bilinear stress-strain behavior of composites made with woven fabrics, ${ }^{24.25}$ with a steeper first part of the curve and a quasi-linear clastic behavior in the following part.

The data obtained from all tensile tests, reported in Table IV, show valid results; as value for the Young modulus of each specimen it has been assumed the average value of initial modulus for each specimen. The comparison with literature data on jute reinforced composites and glass-E shows that the reinforcement hemp composite gives good mechanical properties in traction.

Also specimens from pure resin have been realized, in order to compare the mechanical properties with those declared by the manufacturer and to verify that the curing process had not degraded the epoxy. Test results are reported in Table V.

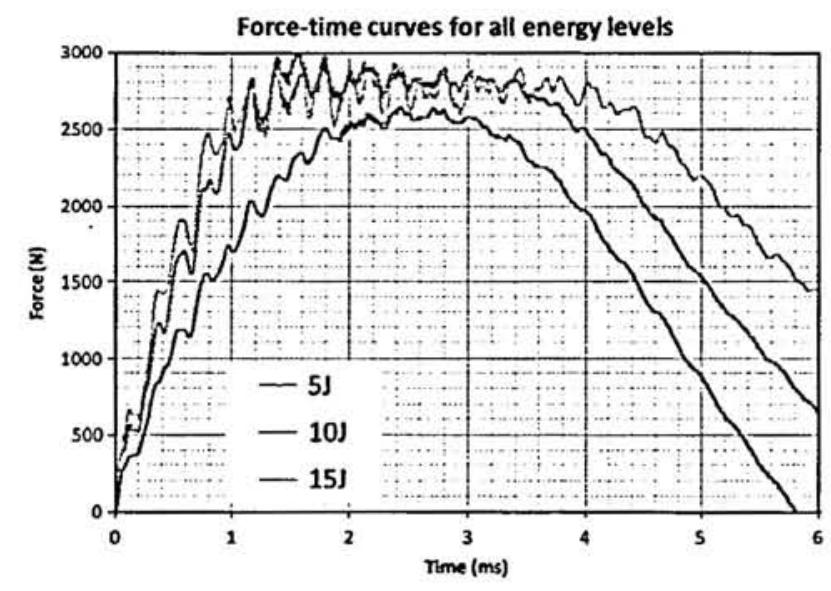

Fig. 12. Force-time curves for all impact energy levels. 


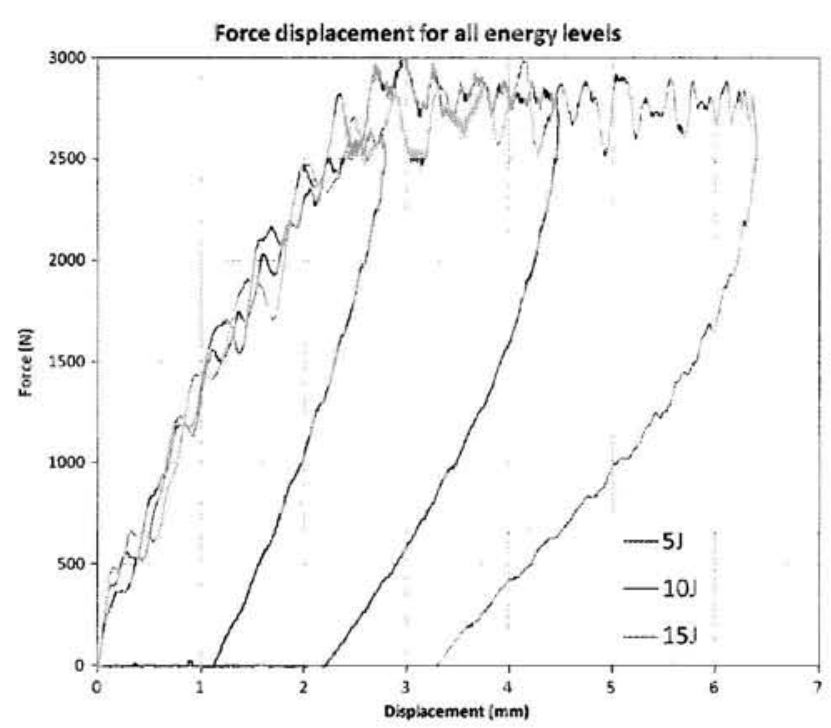

Fig. 13. Force-displacement curves for all impact energy levels.

\section{2. $4 \mathrm{PBT}$}

From the stress-deflection curves (Figs. 10 and 11) it is possible to obtain information rupture mode. Since the trend is not linear and the slope of the curve decreases, rupture is probably due to shear stresses. Tests results are reported in Table VI.

\subsection{Impact Tests}

The encrgies were not sufficient to produce the perforation of the laminates, therefore impact resulted in striker rebound.

Information were available from the images of the impacted specimens, acquired also in backlight, and from Force versus Displacement, Force versus Time and Velocity versus Time curves recorded during the impact. From Force versus Time curves (Fig. 12) it is possible to see that:

- The shape of all of the Force-displacement and velocity-time curves (Figs. 13 and 17) show impact with rebound (displacement decreases after reaching the maximum load);

- In the case of impact at $5 \mathrm{~J}$ the curve is quasisymmetrical, therefore the energy dissipation is reduced;

- The other two curves show more energy dissipation, because of more marked asymmetry between the

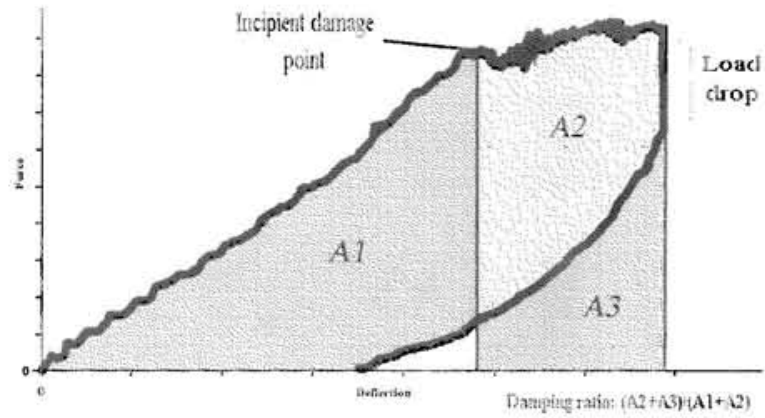

Fig. 14. Typical Force-displacement curve creating a closed loop. Reproduced with permission from [30], C. Santulli, J. Mater. Sci. Lett. 22, 1557 (2003). (1) 2003, Springer.

Table VIII. Results for hemp plain weave/epoxy $5.1 \mathrm{~mm}$ thickness laminates.

\begin{tabular}{|c|c|c|c|c|c|c|c|}
\hline $\begin{array}{l}\text { Impact } \\
\text { energy } \\
\text { (J) }\end{array}$ & $\begin{array}{l}\text { A } 1 \\
(J)\end{array}$ & $\begin{array}{l}\text { A2 } \\
\text { (J) }\end{array}$ & $\begin{array}{l}\mathrm{A} 3 \\
\text { (J) }\end{array}$ & $\begin{array}{l}\text { Damping } \\
\text { ratio }\end{array}$ & $\begin{array}{l}\text { Linear } \\
\text { stiffness } \\
(\mathrm{KN} / \\
(\mathrm{mm})\end{array}$ & $\begin{array}{l}\text { Load } \\
\text { drop } \\
\text { (N) }\end{array}$ & $\begin{array}{c}\text { Load } \\
\text { drop/ } \\
\text { maximum } \\
\text { load }(\%)\end{array}$ \\
\hline \multicolumn{8}{|l|}{5} \\
\hline Average & 2.547 & 0.211 & 0.755 & 0.351 & 1.175 & 82 & 3.1 \\
\hline CV (\%) & 2.1 & 25.3 & 19.3 & 20.6 & 4.7 & 17.3 & 17.6 \\
\hline \multicolumn{8}{|l|}{10} \\
\hline Average & 3.409 & 3.861 & 2.224 & 0.837 & 1.229 & 153 & 5.3 \\
\hline $\mathrm{CV}(\%)$ & 2.6 & 1.7 & 1.1 & 1.4 & 3.2 & 6.6 & 8.0 \\
\hline \multicolumn{8}{|l|}{15} \\
\hline Average & 3.748 & 7.685 & 3.020 & 0.936 & 1.240 & 192 & 6.5 \\
\hline CV $(\%)$ & 1.5 & 1.1 & 5.1 & 1.9 & 1.2 & 5.5 & 7.5 \\
\hline
\end{tabular}

loading-unloading parts and because of rapid fluctuations due to progressing damage.

From the force-time curves it is also possible to measure the maximum load and the consequent onset of first damage. Results are reported in Table VII together with the maximum displacement and the time at which maximum displacement is measured.

The force-displacement graph (Fig. 14) shows clearly that loading and unloading phases do not coincide: rather a closed loop is apparent; its area $(A 1+A 2)$ represents the energy absorbed by the specimen, dissipated by damage mechanisms, and will be referred as total hysteresis energy.

According also to Santulli. ${ }^{30}$ and referring to Figure 14, variables measured are: the slope of the quasi-elastic part of impact curve, referred to as linear stiffness, maximum load, load drop (an indicator of damage severity), and damping ratio, defined as the ratio between the non

Table VII. Impact resuits for hemp plain weave reinforced composites.

\begin{tabular}{|c|c|c|c|c|c|c|c|c|c|}
\hline $\begin{array}{l}\text { Impact } \\
\text { energy (J) }\end{array}$ & $\begin{array}{c}\text { Incipient } \\
\text { damage time } \\
\text { (average) (ms) }\end{array}$ & $\begin{array}{c}\text { Var. coeff. } \\
(\%)\end{array}$ & $\begin{array}{c}\text { Displ. (average) } \\
(\mathrm{mm})\end{array}$ & $\begin{array}{l}\text { Var. coeff. } \\
(\%)\end{array}$ & $\begin{array}{c}\text { Max displ. } \\
\text { (average) (mm) }\end{array}$ & $\begin{array}{c}\text { Var. coeff. } \\
(\%)\end{array}$ & $\begin{array}{l}\text { Max displ. time } \\
\text { (average) (ms) }\end{array}$ & $\begin{array}{c}\text { Max force } \\
\text { (average) }(\mathrm{N})\end{array}$ & $\begin{array}{l}\text { Var. coeff. } \\
(\%)\end{array}$ \\
\hline 5 & 2.02 & 4.9 & 2.41 & 3.6 & 2.79 & 2.8 & 3.10 & 2689 & 1.9 \\
\hline 10 & 1.15 & 1.4 & 2.31 & 1.3 & 4.58 & 2.7 & 3.64 & 2989 & 0.8 \\
\hline 15 & 0.97 & 1.1 & 2.47 & 0.95 & 6.44 & 2.8 & 4.37 & 2996 & 4.1 \\
\hline
\end{tabular}




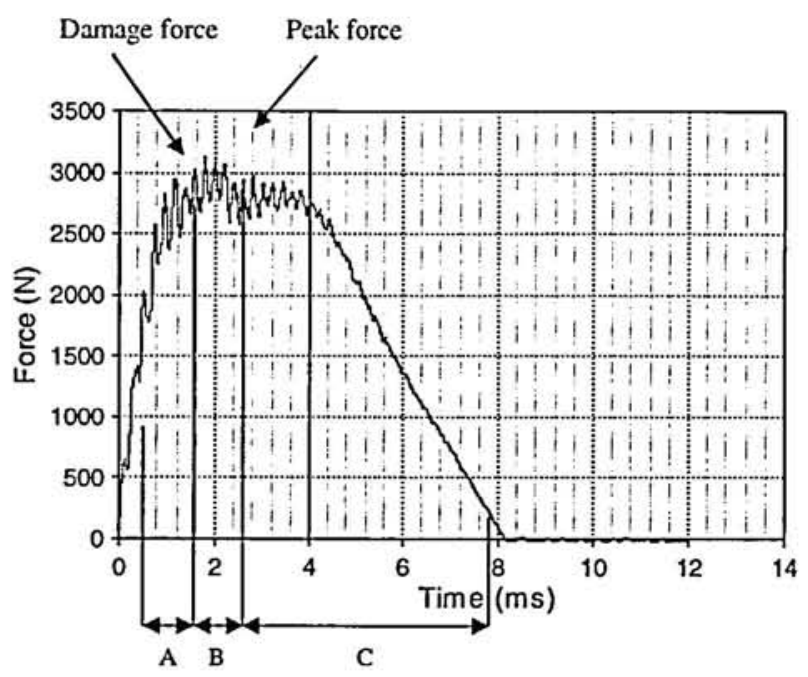

Fig. 15. Load-time curve for the $15 \mathrm{~J}$ impacted specimen (impact with no perforation).

elastic energy $(A 2+A 3)$ and the total hysteresis energy $(A 1+A 2)$. These are all reported in Table VIII. In particular, from the force-displacement curves of Figure 13 it can be seen that the stiffness, after reaching the first damage load, decreases continuously due to material plasticity; for this reason the entity of the load drop is small and not very evident: in other words, progressive damage is observed.

When the striker stops without rebounding it is generally possible to divide the plot into three typical zones ${ }^{11,31}$ that have also been reported in Figure 17:

(a) elastic response (with dynamical perturbations) until the yield force is reached;

(b) from the first material damage until the peak force (with substantial perturbations due to damage development

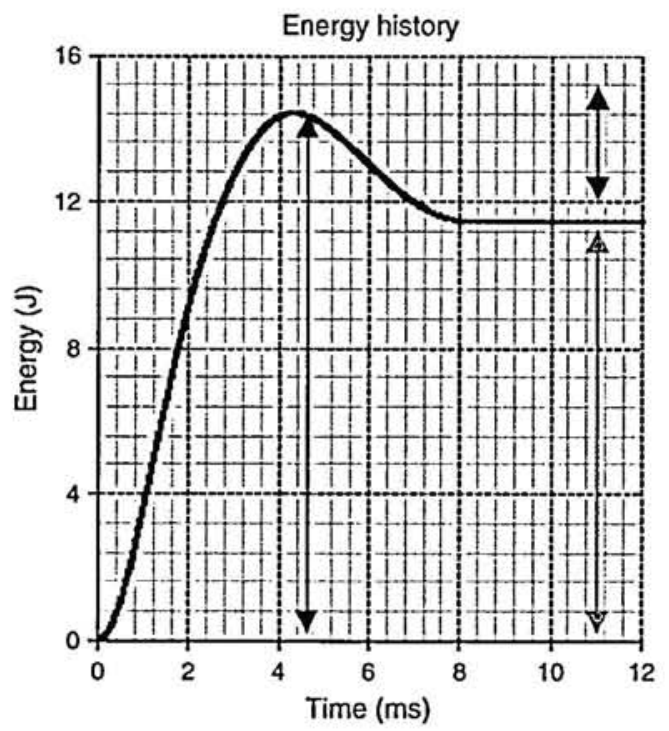

Fig. 16. Energy-time curve; the red arrow indicates $E_{\text {impat }}$, the green one $E_{\text {absorted }}$ and the black one $E_{\text {elassic }}$.

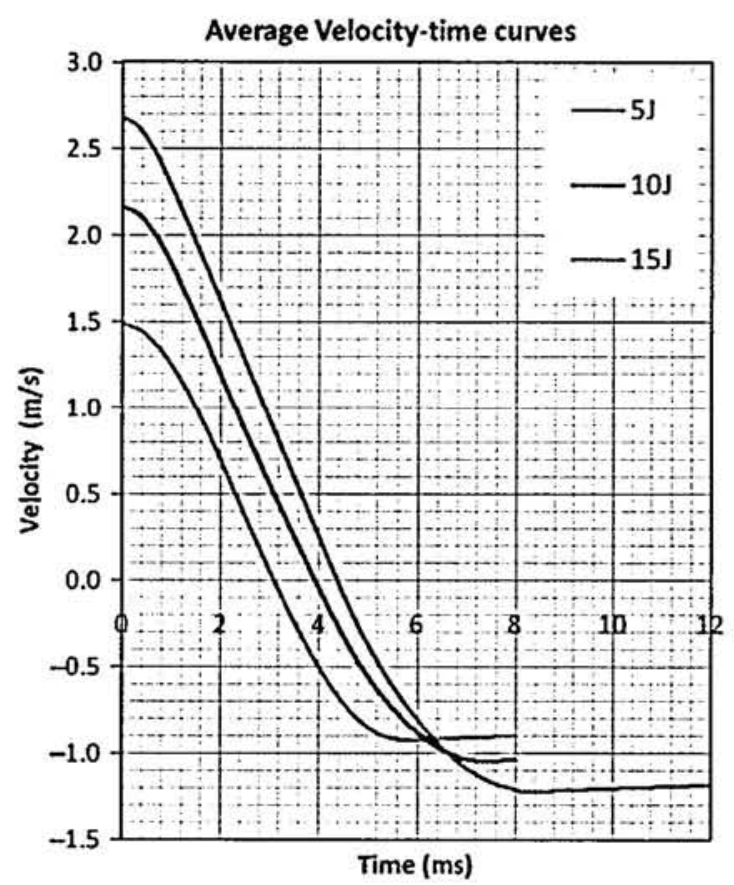

Fig. 17. Average velocity-time curves for all impact energy levels.

with formation of internal cracks and propagation of delaminations);

(c) force decrease, indicating the propagation of rupture phenomena.

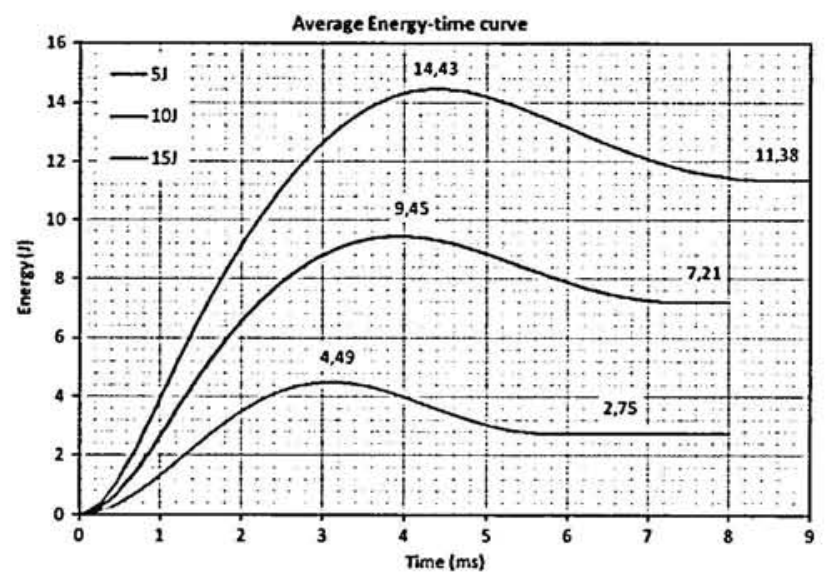

Fig. 18. Energy-time curves for different energy levels.

Table IX. Plain weave hemp/epoxy specimens impact performance.

\begin{tabular}{ccccc}
\hline & $\begin{array}{c}\text { Impact } \\
\text { energy }(\mathrm{J})\end{array}$ & $\begin{array}{c}\text { Energy } \\
\text { absorbed }(\mathrm{J})\end{array}$ & $\begin{array}{c}\text { Max. load } \\
(\mathrm{N})\end{array}$ & $\begin{array}{c}\text { Max. Displ. } \\
(\mathrm{mm})\end{array}$ \\
\hline Average value & 5 & $2.76 \pm 0.008$ & $2689 \pm 52$ & $2.79 \pm 0.077$ \\
& 10 & $7.26 \pm 0.045$ & $2989 \pm 24$ & $4.58 \pm 0.13$ \\
& 15 & $11.43 \pm 0.147$ & $2996 \pm 124$ & $6.44 \pm 0.17$ \\
$\begin{array}{c}\text { Coefficient of } \\
\text { variation (\%) }\end{array}$ & 5 & 0.29 & 1.93 & 2.75 \\
& 10 & 0.63 & 0.80 & 2.74 \\
& 15 & 0.01 & 4.14 & 2.78 \\
\hline
\end{tabular}

J. Biobased Materials and Bioenergy 3, 298-310, 2009 
Table $\mathrm{X}$. Jute glass and hybrid vynilester composites specimens characteristics. 5.6

\begin{tabular}{llccc}
\hline $\begin{array}{l}\text { Specimen } \\
\text { code }\end{array}$ & \multicolumn{1}{c}{ Lay-up } & $\begin{array}{c}\text { Thickness } \\
(\mathrm{mm})\end{array}$ & $\begin{array}{c}\text { Fiber volume } \\
(\%)\end{array}$ & $\begin{array}{c}\text { Density } \\
\left(\mathrm{g} / \mathrm{cm}^{3}\right)\end{array}$ \\
\hline H14 & 14 hemp & 5.1 & 38 & 1.33 \\
$\mathrm{~J} 10$ & 10 Jute & 8.0 & 52 & 1.05 \\
$\mathrm{~V} 10$ & $10 \mathrm{E}-\mathrm{Glass} 300$ & 4.00 & 35 & 1.55 \\
JV & {$[3 \mathrm{~V} / 2 \mathrm{~J} / 1 \mathrm{~V} / 2 \mathrm{~J} / 6 \mathrm{~V}]$} & 5.0 & 55 & 1.33 \\
$\mathrm{JA}-\mathrm{E} 300$ & {$[4 \mathrm{~V} / 2 \mathrm{~J} / 1 \mathrm{~V} / 2 \mathrm{~J} / 4 \mathrm{~V}]$} & 5.0 & 55 & 1.32 \\
JB-E 600 & {$[2 \mathrm{~V} / 2 \mathrm{~J} / 1 \mathrm{~V} / 2 \mathrm{~J} / 2 \mathrm{~V}]$} & 5.0 & 53 & 1.36 \\
JX-E 600 & {$[1 \mathrm{~V} / 2 \mathrm{~J} / 1 \mathrm{~V} / 2 \mathrm{~J} / 3 \mathrm{~V}]$} & 5.0 & 53 & 1.35 \\
\hline
\end{tabular}

In Figure 16 it is shown a typical curve of the energy given from the striker to the specimen (for the $15 \mathrm{~J}$ impacted specimen).

It can be assumed that main contributions are represented from energies of elastic deformation and energy dissipated during damage. " While the first one is conservative, hence comes back to zero when the load is removed, the second one represents the proportion lost due to irreversibility of the process. Referring also to Figure 16 it can be seen that after the maximum ( $\left.E_{\text {impact }}\right)$ is reached, the trend of energy is decreasing until a constant level of energy ( $\left.E_{\text {absorbed }}\right)$ is reached at the end of the test.

$$
E_{\text {impact }}=E_{\text {elastic }}+E_{\text {absorbed }}(\text { Ref. [11] })
$$

$E_{\text {absorbed }}$ is the asymptotic Energy value and can be parted in two terms: energy expended to generate the damage $\left(E_{\text {damagc }}\right)$ and energy absorbed by the system by various means, such as vibrations, heat, anelastic behavior, etc. $\left(E_{\text {disp }}\right)$ :

$$
E_{\text {absorbed }}=E_{\text {damage }}+E_{\text {disp }}(\text { Ref. [11]) }
$$

The damage energy $E_{\text {damage }}$ itself can be divided in 3 major components necessary for: indentation $E_{\text {indentation }}$, matrix damage $E_{\mathrm{dm}}$ and fiber rupture $E_{\mathrm{df}}$.

A comparison between the three average curves obtained for each impact energy level follows below (Fig. 18 and Table IX).

Results obtained from impact test are reported in the following table.

The response of a laminated plate specimen to out-ofplane dynamic impact is affected by the characteristics of the impactor, such as mass and velocity, and, hence, drop height and impact energy, and depends also from target characteristics, as well as impact test setups. ${ }^{32}$ As a consequence, comparisons cannot be made between laminates unless identical test configurations, conditions, and specimen geometries are used. In particular it is known from literature that thickness is one of the main parameters involved in impact phenomena; ${ }^{9}$ also, out-of-plane curvature, stacking sequence and reinforcement architecture (tapes, weaves, and textiles) of the impacted laminate greatly affect its response and damaging process.

Results of this work will be compared with the ones obtained by the same authors in similar conditions (specimen geometry, impact energy, boundary conditions) in previous studies conducted on jute, glass and jute/glass hybrid laminates, made by hand lay-up with vynilester matrix. These results are reported in Tables X and XI. ${ }^{5.6}$ In this work the constant parameter was the mass, so the density/thickness ratio is the same for all specimens.

Because of the importance of thickness in impact response, from this comparison can not be deduced any general results about impact behavior. However it can give us important indications on the possible application of this material, where also some impact resistance is required.

Even for the $15 \mathrm{~J}$ impact there has been no perforation, but an indentation of depth comparable with specimen thickness has been measured. ${ }^{5,6}$

For cost reasons it has not been possible an ultrasound analysis, hence it is not possible to evaluate the internal damage status of the material. However by means of visual backlight analysis it was possible to verify that visible damaged area increased with increasing impact energy.

In Figure 19 are shown damaged surfaces on the side opposite to impact: for the $5 \mathrm{~J}$ impacted specimens damage is limited and no preferential directions of damage can be seen, while these are clearer in the $10 \mathrm{~J}$ and $15 \mathrm{~J}$ cases. It is also apparent that the delamination propagation it is not regular: especially near the center delaminations do not immediately head for $0 \% 190^{\circ}$ directions (probably due to fabric defects, irregularities...), but that they begin on $\pm 45^{\circ}$ and then turn to $0^{\circ} / 90^{\circ}$. At $15 \mathrm{~J}$ energy, from the damage extension, it can also be stated that a slightly higher energy would have probably led to penetration.

\begin{tabular}{|c|c|c|c|c|c|c|}
\hline \multirow[b]{2}{*}{ Specimen code } & \multicolumn{3}{|c|}{ Max contact force } & \multicolumn{3}{|c|}{ Energy absorbed } \\
\hline & $5 \mathrm{~J}$ impact $(\mathrm{KN})$ & $10 \mathrm{~J}$ impact $(\mathrm{KN})$ & $15 \mathrm{~J}$ impact (KN) & $5 \mathrm{~J}$ impact $(\mathrm{J})$ & $10 \mathrm{~J}$ impact $(\mathrm{J})$ & $15 \mathrm{~J}$ impact $(\mathrm{J})$ \\
\hline H14 & 2.64 & 2.94 & 2.92 & 2.76 & 7.26 & 11.43 \\
\hline J10 & 2.70 & 4.10 & $3.60^{s}$ & - & - & - \\
\hline V10 & 3.50 & 4.70 & 5.60 & 4.880 & 8.480 & $11.9^{a}$ \\
\hline JV & 4.00 & 6.00 & $6.70^{a}$ & 4.550 & 7.880 & $12.45^{a}$ \\
\hline JA-E 300 & 4.50 & 5.00 & $6.20^{a}$ & 4.950 & 8.200 & $12.1^{a}$ \\
\hline JB-E 600 & 4.20 & 5.60 & $6.4^{a}$ & 4.375 & 8.880 & $12.45^{a}$ \\
\hline JX-E 600 & 4.10 & 4.90 & $6.1^{a}$ & 4.380 & 7.890 & $11.7^{a}$ \\
\hline
\end{tabular}

Table XI. Jute, glass and hybrid vinylester composites impact performance compared to hemp/epoxy. 5

V: glass fiber, J: jute fibers; H: Hemp fibers; ${ }^{a}$ interpolated result between $14 \mathrm{~J}$ and $16 \mathrm{~J}$; ${ }^{b}$ experimental; perforation without trespassing. 


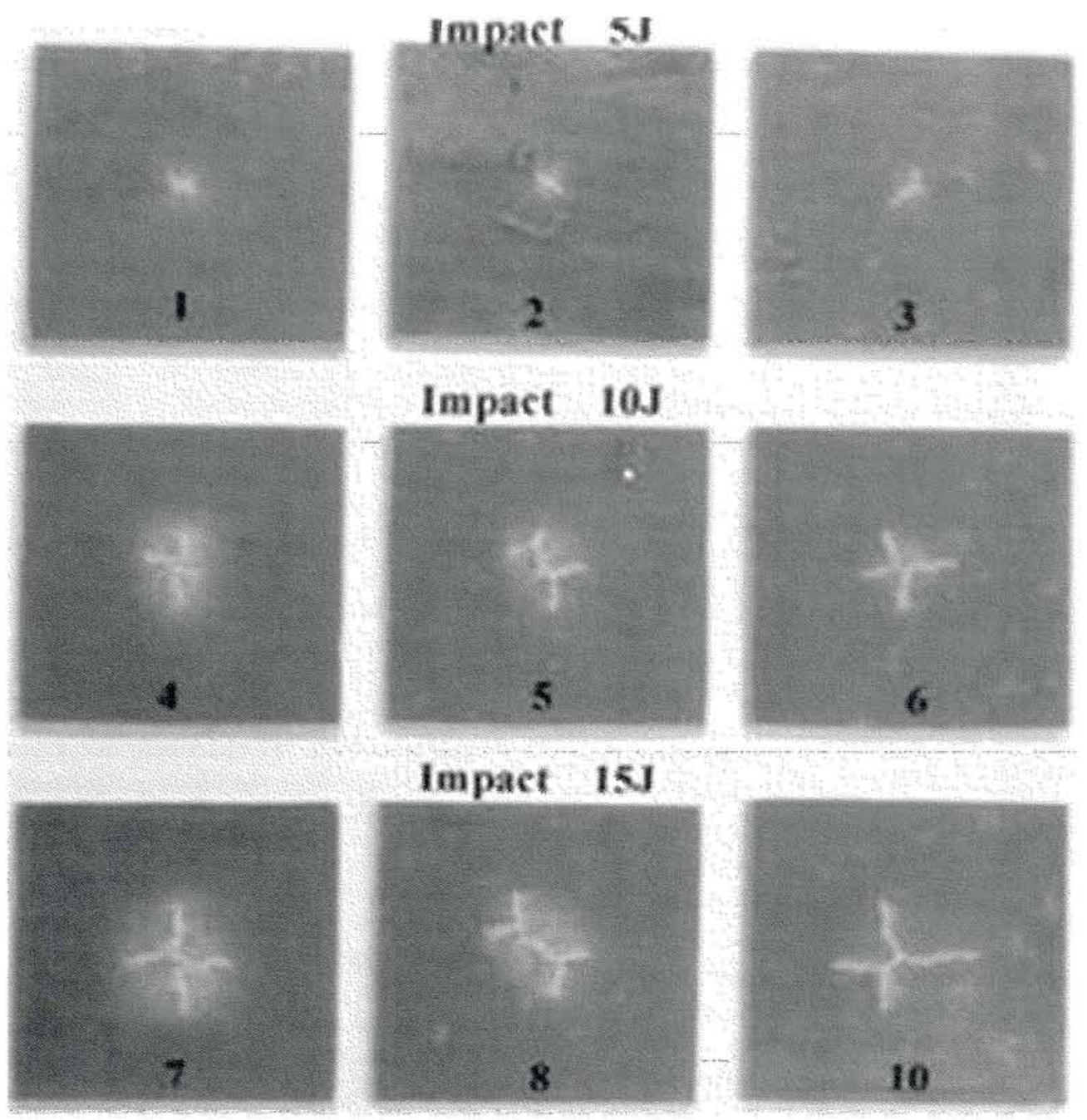

Fig. 19. Back surfaces of impacted specimens ( 3 for each energy level, one level per line, from $5 \mathrm{~J}$ to $15 \mathrm{~J}$.

For this reason higher energy impacts has not been performed.

The following pictures (Figs. 20, 21, 22) show a $40 \times$ $40 \mathrm{~mm}$ area around the impact point.

From these images the damaged area can be calculated very approximately as the surface of a circle whose diameter is the largest dimension of the damage. However, data obtained by this method cannot be compared with ultrasound results, because they provide only an estimate of damaged area trend at various impact energy; results are reported in Figure 23 and Table XII; an almost linear trend has been found.

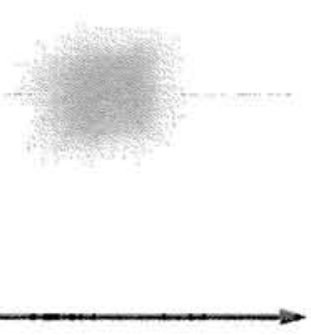

Fig. 20. Impact point of $5 \mathrm{~J}$ impacted specimens $(10 \times 10 \mathrm{~cm})$, backlight picture. 


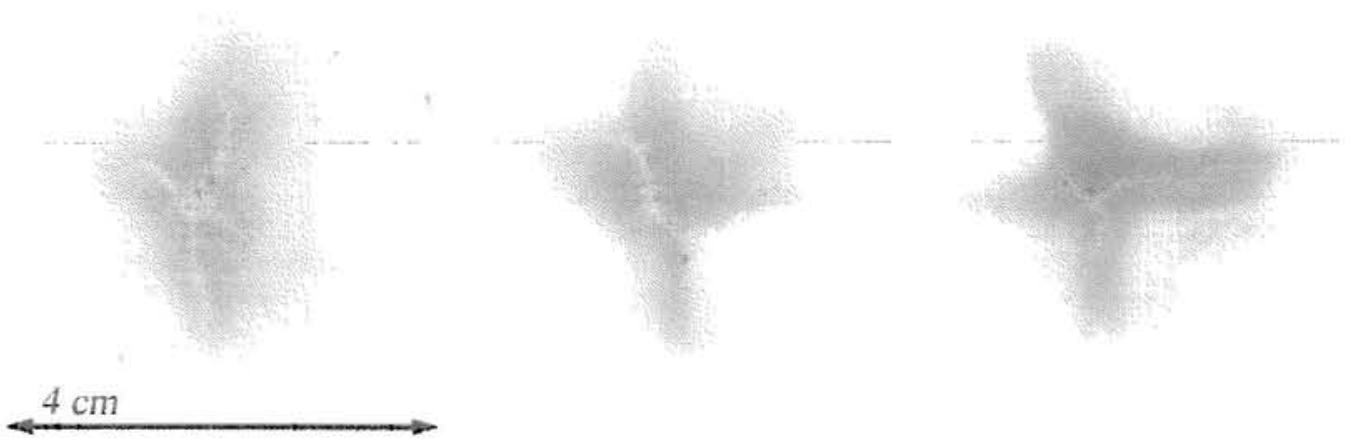

Fig. 21. Zoom on $10 \mathrm{~J}$ impacted specimens $(10 \times 10 \mathrm{~cm})$, backlight picture.
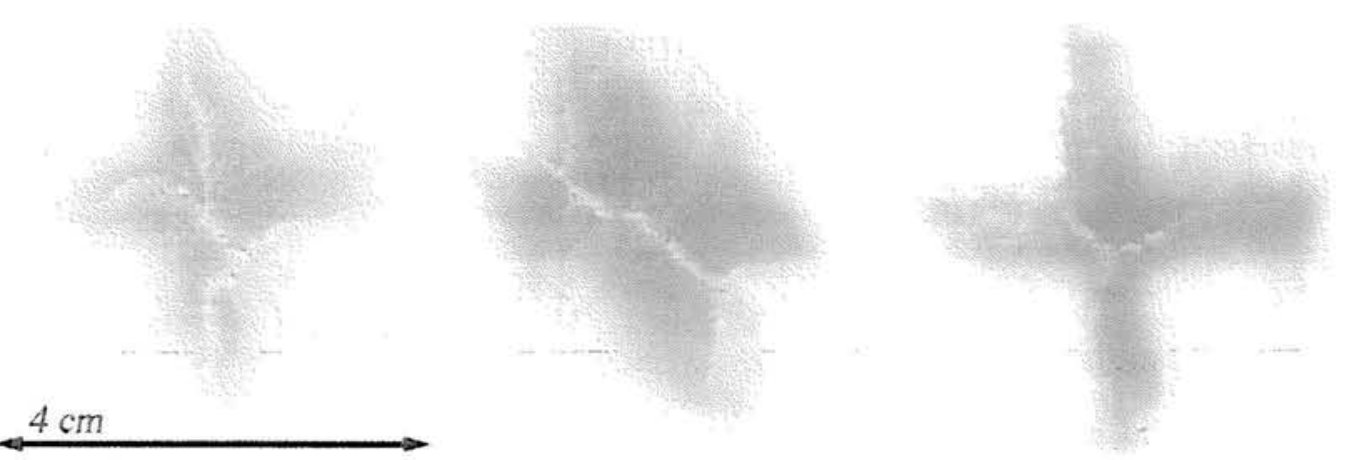

Fig. 22. Zoom on $15 \mathrm{~J}$ impacted specimens $(10 \times 10 \mathrm{~cm})$, backlight picture.

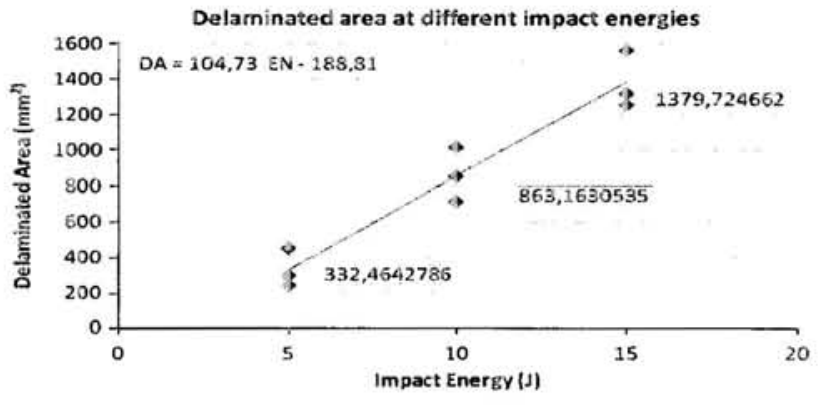

Fig. 23. Estimated delaminated area for all impact energy leveis.

Table XII. Estimated delaminated area for all impact energy levels.

\begin{tabular}{lccc}
\hline Impact Energy $(\mathrm{J})$ & 5 & 10 & 15 \\
Delaminated area $\left(\mathrm{mm}^{2}\right)$ & 332 & 863 & 1380 \\
Standard Deviation $\left(\mathrm{mm}^{2}\right)$ & 108 & 151 & 161 \\
Coefficient of Variation $(\%)$ & 32.45 & 17.49 & 11.69 \\
\hline
\end{tabular}

\section{CONCLUSIONS AND POSSIBLE FUTURE DEVELOPMENTS}

From the above results, the following main conclusions can be traced:

- An RTM system, originally intended for glass and/or carbon fiber, proved effective with hemp fibers fabric/ epoxy.
- It has been proven experimentally that process parameters (such as pressure-time curves, degassing procedures...) greatly influence the final product.

- The process has been partially improved with negligible cost aggravation. Further enhancements are possible by changing parameters, such as geometry and number of resin inlet holes, pressure-time curves, curing process, etc.

- In spite of the few analysis tools available, it can be stated that the RTM hemp/epoxy composite exhibits a good impact behavior respect to other NFCs.

- It can be confirmed that hemp can be used as a reinforcement alternative to glass for semi-structural structures. However, other tools of analysis e.g., ultrasound after impact testing and residual properties measurements, would also be needed for a sounder characterization of impact behavior of this material.

Acknowledgments: Ing. Fulvio Ferraro of the CSM for the RTM process; (CSM: Centro Sviluppo Materiali s.p.a., via di Castel Romano n. 100, cap 00128 Roma). Ing Teresa Vetere for the resistance tests. Professor Carlo Santulli.

\section{Ref́erences}

1. T. Yuanjian and D. H. Isaac, Compos. Sci. Technol. 67, 3300 (2007).

2. M. Karus, S. Ortmann, and G. D. Vogt, Use of Natural Fibres in Composites in the German Automotive Production 1996 till 2003 Nova-Institute, September (2004). 
3. O. A. Khondker, U. S. Ishiaku, A. Nakai, and H. Hamada, Composites, A 37, 2274 (2006).

4. D. J. Elder, R. S. Thomson, M. Q. Nguyen, and M. L. Scott, Composite Structures 66, 677 (2004).

5. G. Briotti, C. Caneva, M. Valente, and C. Scarponi, Impact behaviour of jute fibers composites, Proceedings International Conference Composite Engineering ICCE/8, August, Tenerife (2001).

6. G. Briotti, C. Caneva, M. Valente, and C. Scarponi, Experimental evaluation of delaminations for low-cost composite laminates impacted at low-velocity, Proceedings International Conference Composite Engineering ICCEת, July, AIPnD, Italian Society for Non-Destructive Testing and Monitoring Diagnostics, Denver (USA) (2000).

7. N. Keršienë• and A. Žiliukas, Mechanika 6, 56 (2005).

8. V. Tita, J. de Carvalho, and D. Vandepitte, Composite Structures 83, 413 (2008).

9. T. L. Anderson, Fracture Mechanics-Fundamentals and Applications, CRC Press, New York (1995).

10. S. Abrate, Impact on Composite Structures, Cambridge University Press, London (1998).

11. C. Scarponi, G. Briotti, R. Barboni, A. Marcone, and M. Iannone, J. Compos. Mater. 30, 17 (1996).

12. F. K. Chang and K. Y. Chang, J. Compos. Mater. 21, 834 (1987).

13. C. Santulli and W. J. Cantwell, J. Mater. Sci. Lett. 20, 477 (2001).

14. C. Santulli, Science and Engineering of Composite Materials 9, 177 (2000).

15. H. N. Dhakal, Z. Y. Zhang, M. O. W. Richardson, and O. A. Z. Errajhi, Compos. Struct. 81, 559 (2007).

16. H. D. Mueller and A. Krobjilowski, International Nonwovens Journal 13, 31 (2004)

17. C. Scarponi, D. Maglione, G. Cosentino, and F. Lenzi, Hemp fabrics for natural fibres composites industrial applications, Dipartimento di Ingegneria Aerospaziale e Astronautica, Sapienza-Università di Roma, TEMA (Technological and Advanced Material Laboratories) of CIRA (Centro Italiano Ricerche Aerospaziali, Capua (CE)), Article in press, IJMPT (2009), Vol. 36, pp. 1-4.

18. C. Scarponi and G. Briotti, J. Reinf. Plast. Compos. 16, 768 (1997).

19. G. Caprino, V. Lo Presto, C. Scarponi, and G. Briotti, Compos. Sci. Technol. 59, 2279 (1999).

20. C. Scarponi and G. Briotti, Composites Part B 31, 237 (2000).

21. G. Briotti, C. Caneva, M. Valente, and C. Scarponi, Delamination on impacted natural fibers composite materials by means of a new ultrasonic methods, Proceedings Structural Health Monitoring, September, IVSHM, Stanford (2001).

22. C. Scarponi and M. Valente, Int. Journal of Materials and Product Technology 26, 6 (2006).

23. T. Vetere, Caratterizzazione del danno da impatto di materiali compositi rinforzati con fibre di canapa, Dipartimento di Ingegneria Aerospaziale e Astronautica, Sapienza-Università di Roma, degree thesis (2008).

24. I. Herszberg, P. J. Falzon, K. H. Leong, and M. K. Bannister, Bearing strength of glasss/epoxy composites manufactured from weft-knitted E-glass fabric, Proc. Conf. 1st Australian Congress on Applied Mechanics, Melbourne, Australia, The Institution of Engineers, Australia (1996), Vol. 1, pp. 279-284.

25. S. Chabba and A. N. Netravali, JSME International Journal, Series A 47, 556 (2004).

26. Y. Shindo, S. Takano, K. Horiguchi, and T. Sato, Cryogenics 46, 794 (2006).

27. D. G. Hepworthl, R. N. Hobson, D. M. Bruce, and J. W. Farrent, Composites: Part A 31, 1279 (2000).

28. M. Hautala, A. Pasila, and J. Pirila, Composites: Part A 35, 11 (2004).

29. K. Sever, M. Sarikanat, Y. Seki, V. Cecen, and I. H. Tavman, J. Mater. Sci. 43, 4666 (2008).

30. C. Santulli, J. Mater. Sci. Lett. 22, 1557 (2003).

31. G. Belingardi, R. Vadori, Int. J. Impact Eng. 27, 213 (2002).

32. P. Feraboli, Journal of Aircraft 43, 1336 (2006). 